\title{
HUBUNGAN IMOTIVASI RELIGIUS DENGAN PENINGKATAN PRESTASI BELAJAR PESERTA DIDIK
}

\author{
Muh. Amin \\ No.HP : 085242350052 \\ Nama Institusi: Ma'had Radhiyatul Ma'arif Li Tahfidz al-Qur'an Makassar \\ Email: onhe17@gmail.com
}

\begin{abstract}
One of the main benchmarks for perceiving the triumph of learning of student is by beholding the extent to which learning achievements are attained. Learning achievement is the degree to which student's knowledge of the given material is received.This study focuses on the extent to which religious motivation of the students relates to their learning achievements. Data were obtained by using a questionnaire. The subjects of this study were 116 students of Madrasah Aliyah Negeri 1 Makassar. The data were analyze with descriptive correlational analysis.The result of this study indicates a significant relationship between religious motivation and student achievements. There is 0,233 of correlation coefficient with a significance of 0,001. Hypothesis was tested by comparing the significance level ( $p$-value)with matrix that if the significance is 0,05 then Ho is accepted, if significance $<0,05$, then $\mathrm{Ho}$ is rejected and $\mathrm{Ha}$ is accepted. In this case, it could be seen that there is 0,233 of the correlation coefficient with 0,001 if significance. Owing to that significance which is $<0.05$ then $\mathrm{Ho}$ is rejected and $\mathrm{Ha}$ is accepted.
\end{abstract}

Keywords: Motivation, Religious, Learning Achievement

\section{PENDAHULUAN}

\section{A. Latar Belakang}

Salah satu tujuan pendidikan adalah menciptakan suasana belajar dan proses belajar yang memungkinkan siswa untuk secara aktif mengembangkan agama, spiritual, kontrol diri, kepribadian, kebijaksanaan, kualitas mulia dan potensi keterampilan mereka. Salah satu upaya untuk mencapai tujuan ini adalah meningkatkan prestasi siswa. Prestasi belajar adalah tolak ukur utama untuk memahami keberhasilan pembelajaran. Seseorang dengan prestasi tinggi dapat mengatakan bahwa ia telah berhasil belajar. Prestasi belajar adalah pemahaman siswa tentang materi yang diperoleh.

Prestasi belajar yang dicapai seseorang adalah hasil interaksi antara berbagai faktor, faktor internal dan faktor eksternal. Memperkenalkan faktor-faktor yang mempengaruhi kinerja belajar penting untuk membantu siswa mencapai prestasi belajar terbaik. Kadangkadang kegiatan belajar setiap siswa tidak dapat berjalan secara alami, kadang-kadang tidak, kadang-kadang mereka dapat dengan cepat menangkap apa yang telah mereka 
pelajari, dan kadang-kadang sulit. Dalam hal antusiasme, terkadang antusiasme tinggi, tetapi terkadang sulit untuk berkonsentrasi. ${ }^{1}$

Setiap siswa sering menemukan fakta yang berkaitan dengan kegiatan belajar dalam kehidupan sehari-hari mereka, dan setiap siswa berbeda. Perbedaan ini menyebabkan perbedaan dalam perilaku belajar siswa. Setiap siswa memiliki karakteristiknya sendiri sebagai individu dan subjek pembelajaran. Kondisi yang berisi setiap siswa akan mempengaruhi proses belajar siswa.

Salah satu faktor yang harus dimiliki siswa dalam meningkatkan prestasi belajar mereka adalah motivasi. Siswa membutuhkan motivasi, sehingga mereka sangat bersemangat. Maslow dalam Syaiful sangat percaya bahwa perilaku manusia dipicu dan dibimbing oleh kebutuhan tertentu seperti kebutuhan fisiologis, keamanan, cinta, penghargaan, realisasi diri, pengetahuan dan pemahaman, dan kebutuhan estetika. Menurut Maslow, kebutuhan ini yang membuat individu dapat termotivasi. ${ }^{2}$

Berdasarkan sudut pandang ini, dapat dilihat bahwa motivasi pada diri siswa pasti berbeda, jadi ketika itu terkait dengan prestasi belajar, kelancaran belajar yang akan dialami siswa berbeda. Menurut Anni, ada enam faktor yang memengaruhi motivasi belajar siswa, termasuk sikap, kebutuhan, rangsangan, emosi, kemampuan, dan penguatan. ${ }^{3}$ Singgih D. Gunarsa menjelaskan motivasi intrinsik dan ekstrinsik Motivasi intrinsik adalah motivasi yang kuat dalam diri seseorang, dan motivasi ekstrinsik adalah segala sesuatu yang disarankan atau didorong melalui pengamatan diri atau melalui nasihat orang lain. ${ }^{4}$

Salah satu hal yang mempengaruhi kemampuan siswa untuk mendemonstrasikan disiplin adalah bahwa mereka memahami agama sebagai cara untuk mendorong sikap dan perilaku tanpa melanggar norma-norma yang berlaku pada lingkungan mereka. Seperti yang kita semua tahu, agama adalah cara hidup dalam kehidupan manusia, dan mereka memberikan panduan untuk semua aspek kehidupan. Sebagai umatnya dan kekhalifahan, kehidupan manusia di dunia memiliki tugas suci untuk menyembah dan melayani Allah SWT dengan mempraktikkan doktrin agama, yang berarti bahwa manusia, sebagai keberadaan yang paling sempurna, mencoba untuk menemukan identitas mereka sendiri dan mengembangkan nilai kemanusiaan yang tertinggi dalam bentuk ibadah. ${ }^{5}$

Sejak manusia mulai berinteraksi dengan lingkungan sekitar, lingkungan keluarga, manusia telah memahami agama, dan kedua orang tua mengajarkan kepercayaan agama di sini. Ketika jiwa berkembang, ia mulai merasakan impuls lain yang terkait dengan proses agamanya. Dengan kata lain, dorongan pikiran bukan hanya karena orang tua, tetapi karena hal-hal di luar. Proses pergeseran impuls dari faktor keluarga ke faktor lain

1Ahmadi, Psikologi Sosial (Cet. III; Jakarta: PT. Rineka Cipta, 2004), h. 138.

2Syaiful B. Djamarah,Psikologi Belajar (Cet. III; Jakarta: PT. Rineka Cipta, 2011), h. 115.

3Tri Chatarina Anni, Psikologi Belajar (Semarang: UPT MKK UNNES, 2007), h. 158.

4Singgih D. Gunarsa, Psikologi Olahraga Prestasi (Jakarta: Gunung Mulia,2008), h. 50-51.

5Hasan Langgulung, Manusia dan Pendidikan Suatu Analisa Psikologi dan Pendidikan (Cet. III; Jakarta: al-Huda Zikra, 1995), h. 59. 
bervariasi dari orang ke orang. Agama adalah faktor terpenting dalam diri seseorang. Jika kepercayaan agama telah menjadi bagian dari kepribadian seseorang, maka kepercayaan ini akan memonitor setiap gerakan, ucapan, dan bahkan perasaan. ${ }^{6}$

Motif keagamaan seseorang dipengaruhi oleh berbagai faktor internal manusia. Dalam bentuk faktor psikologis, ia sering didorong untuk mematuhi materi. Ini adalah faktor supernatural dan eksternal yang disebabkan oleh manusia karena pengaruh era global. Dampak yang signifikan, tidak ada agama yang dapat dipisahkan dari motif-motif tertentu, walaupun pada tingkat kepercayaan agama seseorang, motivasi bukan lagi satusatunya alasan seseorang menerima agama.

\section{B. Tujuan Penelitian}

Penelitian ini bertujuan untuk mendapatkan data empirik, mendeskripsikan, menganalisis dan menguji seberapa besar hubungan motivasi religius dengan prestasi belajar peserta didik di Madrasah Aliyah Negeri 1 Kota Makassar.Pengembangan di bidang ilmu pendidikan, terkhusus yang berkaitan dengan motivasi religius serta prestasi belajar peserta didik. Sebagai sumbangan pemikiran bagi upaya pendidik dalam meningkatkan prestasi belajar peserta didik melalui membangkitkan motivasi siswa dalam kaitannya dengan pengamalan ibadah, baik yang berkenaan dengan ibadah shalat, baca qur'an, maupun kegiatan-kegiatan ekstrakurikuler lainnya, bahkan diharapkan dapat memberikan kontribusi pemikiran dan memperkaya khasanah keilmuan dalam dunia pendidikan.

Penelitian ini diharapkan menjadi bahan referensi yang dapat memberikan informasi tentang usaha yang harus dilakukan dalam memotivasi peserta didik dalam peningkatan prestasi belajarnya dan dapat menjadi masukan kepada pihak pelaksana pendidikan terutama bagi pendidik di MAN 1 kota Makassar, serta menjadi referensi tertulis bagi calon peneliti berikutnya yang berkeinginan meneliti masalah yang relevan dengan tulisan ini.

\section{KAJIAN TEORI}

\section{A. Motivasi Religius}

Motivasi religius adalah dorongan psikologis yang memiliki dasar ilmiah dari sifat peristiwa manusia. Dalam relung jiwanya, manusia merasakan dorongan untuk mencari dan berpikir tentang pencipta dan pengatur alam semesta, mengagumi impulsnya, dan mencari bantuan dalam menghadapi masalah dan bencana. ${ }^{7}$ 
Muslim mengatakan bahwa motivasi religius juga dapat didefinisikan sebagai gerakan manusia yang berasal dari respon terhadap sistem Ilahi, sehingga orang dapat mengekspresikannya dalam bentuk tindakan dan pemikiran. ${ }^{8}$

Oleh karena itu dapat disimpulkan bahwa motivasi keagamaan adalah sesuatu yang ada pada individu atau seseorang yang mendorong perilaku untuk mencapai tujuan tertentu yang berkaitan dengan keilahian, penghargaan, pemahaman dan praktik doktrin atau kepercayaan agama yang terkandung dalam agamanya.

Motif keagamaan terkait langsung dengan perjalanan spiritual seseorang yang mencari kebahagiaan Allah. SWT. Secara garis besar, motivasi religius terbagi menjadi dua jenis, yaitu motivasi intrinsik adalah motivasi untuk mendapatkan kebenaran melalui kitab suci melalui pemahaman eksternal, motivasi eksternal adalah adanya rangsangan eksternal, karena keturunan atau lingkungan memilih Islam. ${ }^{9}$

Pada tahap awal agama, beberapa orang pasti membutuhkan dua motif ini. Kelanjutan ini adalah panduan yang diperlukan untuk mencapai kasih sayang Allah swt.. Dapat pahami bahwa orang yang paling religius benar-benar bersih dan tidak memiliki motif buruk.

Faktanya, motivasi religius adalah motif dasar yang dimiliki setiap orang sejak lahir, yang disebut fitrah. Motivasi Fitrah sebagai manusia sering diartikan sebagai naluri manusia, naluri ini hanya naluriah bagi manusia bukan naluri binatang, karena menyangkut spiritualitas. ${ }^{10}$

Pada saat yang sama, Yahya Jaya membagi motif agama menjadi dua kategori, yaitu motif agama rendah dan motif agama tinggi. ${ }^{11}$

Jika itu selaras dengan keadaan jiwa muda yang bertransisi dari anak ke dewasa, maka kesadaran religius remaja adalah dalam keadaan transisi dari kehidupan keagamaan anak ke stabilitas agama. Selain keadaan jiwa yang tidak stabil dan mengejutkan, kekuatan pemikiran abstrak, logis dan kritis berkembang. Emosinya hanya tumbuh dengan dorongan makhluk. Keadaan jiwa remaja ini juga muncul dalam kehidupan keagamaan yang mudah goyah, yang berakar dari ketidakpastian, kecemasan, dan konflik batin. $^{12}$

Oleh karena itu, adanya motivasi religius mendorong siswa untuk mengerahkan kreativitas mereka, melakukan perbuatan baik, dan melakukan layanan ibadah dan pengorbanan dalam bentuk properti di jalur pendidikan agama. Ini dibuktikan dengan mendorong siswa untuk jujur, menepati janji, dan menjaga kepercayaan. Motivasi religius ini diharapkan dapat mendorong siswa untuk bertindak dengan itikad baik, diuji, bersyukur atas semua berkat mereka dan berdoa selamanya. Jika sikap ini berasal dari

8Muslim A. Kadir, Ilmu Islam Terapan (Cet. 3; Yogyakarta: Pustaka Pelajar, 2013) h. 44. 9Ramayulis, Psikologi Agama (Jakarta: Kalam Mulia, 2010). h. 76.

10Hamdani Bakran Ad-Dzakiy, Psikologi Kenabian (Yogyakarta: Pustaka Al-Qur'an, 2010). h. 415. 11Ramaliyus, h. 80-81

12Abdul Aziz Ahyadi, Psikologi Agama (Cet. V; Jakarta: Raja Grafindo, 2011). h. 43 
kepercayaan pada agama, maka sikap ini akan lebih mendalam. Keinginan kuat siswa untuk beragama tentu saja akan mempengaruhi potensi pengembangan keberadaan siswa.

\section{B. Prestasi Belajar}

Prestasi belajar semakin penting dan tidak pernah hilang dalam pendidikan karena prestasi belajar mengukur kemajuan dan peningkatan kualitas pendidikan, termasuk kualitas pembelajaran dan lembaga, terutama siswa. Prestasi belajar tidak terlepas dari perilaku belajar, karena belajar adalah proses yang menghasilkan hasil belajar. Keberhasilan atau kegagalan siswa dalam belajar, dengan kata lain, pencapaian prestasi belajar yang baik sangat tergantung pada pengalaman belajar siswa. Pembelajaran yang berkualitas akan menghasilkan hasil belajar siswa yang baik.

Zainal Arifin menjelaskan bahwa kata prestasi berasal dari bahasa Belanda, yaitu "prestatie". Kemudian di Indonesia, kata itu menjadi "prestasi", yang berarti "hasil usaha". Sebagaimana dinyatakan dalam kamus besar Bahasa Indonesia, prestasi adalah hasil yang telah dicapai atau telah selesai. Pius A. Partanto dan M. Dahlan al-Barry juga menyatakan pemahaman yang sama, prestasi adalah hasil yang telah dicapai. Beberapa pandangan di atas tentang konsep pencapaian jelas mengekspresikan perbedaan dalam kata-kata tertentu, tetapi esensinya adalah sama. Hasil yang diperoleh dari suatu kegiatan. Oleh karena itu, dapat dipahami bahwa prestasi adalah hasil dari kerja yang tulus dalam bidang kegiatan tertentu, apakah itu individu atau kelompok, melakukan, menciptakan, dan melibatkan kegiatan.

Selain itu, sesuai dengan definisi para ahli, misalnya, Cronbach mengatakan dalam bukunya Educational Pysychology seperti dikutip oleh Sumadi Suryabrata, "learning is shown by a change in behavior as a result of experience" yang berarti bahwa pembelajaran dimanifestasikan oleh perubahan perilaku.13 Selain itu, masih di Sumadi Suryabrata, Spears berkata "learning is to observe, to read, to imitate, to try something themselves, to listen, to follow direction" yang berarti belajar adalah observasi, membaca, meniru, mencoba, mendengarkan, dan mengikuti instruksi.14

Menurut Slameto, belajar adalah proses usaha yang dilakukan seseorang untuk mengubah perilaku karena ia memiliki pengalaman sendiri berinteraksi dengan lingkungan.15 Belajar adalah proses kegiatan yang mencapai perubahan perilaku sadar berdasarkan pengalaman mereka berinteraksi dengan lingkungan sekitarnya.

Melihat beberapa definisi yang disebutkan di atas, orang dapat menyimpulkan bahwa belajar adalah upaya sadar dan berkesinambungan oleh seseorang untuk mengalami perubahan dalam perilaku keseluruhan dan untuk berinteraksi dengan lingkungan.

Menurut definisi di atas, pemahaman prestasi dan pembelajaran dapat dimasukkan ke dalam definisi beberapa definisi yang dikemukakan oleh para ahli. Prestasi belajar

13Sumadi Suryabrata, Psikologi Pendidikan (Cet. 18; Jakarta: Rajawali Pers, 2011), h. 231.

14Sumadi Suryabrata, Psikologi Pendidikan, h. 231.

15Slameto, Belajar dan Faktor - Faktor yang Mempengaruhinya (Jakarta: Rineka Cipta, 2003), h. 2 
adalah hasil belajar yang dicapai seseorang melalui kegiatan belajar, Anda dapat langsung mengukur atau melihat hasil tes yang diperoleh dalam laporan pendidikan melalui pengujian.

Dalam kamus bahasa Indonesia yang besar, prestasi belajar adalah perolehan pengetahuan atau keterampilan yang dikembangkan melalui mata pelajaran, biasanya dinyatakan dengan nilai tes atau nilai yang diberikan oleh guru.16 Tohirin berkata: "Prestasi Belajar adalah hasil siswa setelah belajar".17 Sedangkan Nana Sudjana prestasi belajar menyebutnya dengan istilah hasil belajar. "Hasil belajar adalah kemampuan siswa untuk memperoleh pengalaman belajar".18

Definisi ini menunjukkan bahwa prestasi siswa pada dasarnya menangkap pengetahuan atau keterampilan dan perubahan perilaku yang diperoleh siswa setelah kegiatan belajar. Prestasi belajar juga dapat diartikan sebagai nilai dari suatu kegiatan yang telah selesai atau diselesaikan secara individu atau dalam suatu kelompok. Prestasi belajar juga merupakan hasil dari mencapai keberhasilan melalui pembelajaran yang maksimal.

\section{METODE PENELITIAN}

Penelitian ini bersifat deskriptif korelasional dengan menggunakan pendekatan kuantitatif, yakni mendeskripsikan mengenai hubungan motivasi religius dengan prestasi belajar peserta didik, korelasional digunakan untuk mempelajari hubungan dua variabel atau lebih, yakni sejauh mana variasi dalam suatu variabel berhubungan dengan variasi dalam variabel lain. Populasi dalam penelitian ini berjumlah 773 orang siswa di MAN 1 Makassar. Sampel diambil 15\% dari jumlah populasi yakni 116 orang peserta didik mengunakan simple random sampling. Teknik simple random sampling dalam penelitian ini digunakan kepada peserta didik kelas XI dan XII Madrasah Aliyah Negeri 1 Kota Makassar dengan pertimbangan bahwa siswa kelas X belum memiliki nilai rapor `yang menjadi acuan pada variabel prestasi belajar dalam penelitian ini.

Teknik pengumpulan data yaitu observasi, skala dan dokumentasi.Teknik analisis yang digunakan yaitu analisis deskriptif dan korelasi. Analisis deskriptif untuk menjelaskan hubungan antara satu variabel dengan variabel yang lain. Analisis korelasi digunakan untuk melihat hubungan dari dua hasil pengukuran atau dua variabel yang diteliti. Dalam mengetahui seberapa besar hubungan dan kemampuan prediksi varibel bebas terhadap variabel terikat. Sebelum dilakukan analisis data, terlebih dahulu dilakukan uji asumsi yang meliputi normalitas sebaran linearitas hubungan variabel bebas dengan variabel terikat. Keseluruhan tekhnik analisis data menggunakan spss versi 23.

16Departemen Pendidikan Nasional, Kamus Besar Bahasa Indonesia, h. 1093.

17Tohirin, Psikologi Pembelajaran Pendidikan Agama Islam (Berbasis Integrasi dan Kompetensi) Ed. I, (Cet. 3; Jakarta: Raja Grafindo Persada, 2008), h. 151.

18Nana Sudjana, Penilaian Hasil Proses Belajar Mengajar (Cet. 15; Bandung: Remaja Rosdakarya, 2010), h. 22. 


\section{HASIL DAN PEMBAHASAN}

\section{A. Hasil}

\section{Gambaran Motivasi Religius Peserta Didik Madrasah Aliyah Negeri 1 Kota Makassar}

Untuk memperoleh gambaran motivasi religius peserta didik di Madrasah Aliyah Negeri 1 Kota Makassar, peneliti menyususn skala motivasi religius sebanyak 30 item. Skor bergerak dari 1 sampai 4 pada setiap motivasi religius. Skor terendah secara hipotetik adalah 34 dan yang tertinggi 114, skor rerata hipotetik pada skala motivasi religius adalah 75 .

Rerata Hipotetik dan Rerata Empirik Motivasi Religius Peserta Didik Madrasah Aliyah Negeri 1 Kota Makassar.

\begin{tabular}{|c|c|c|c|c|c|c|c|c|c|}
\hline Variabel & $\mathbf{N}$ & \multicolumn{4}{|c|}{ Data Hipotetik } & \multicolumn{4}{c|}{ Data Empirik } \\
\hline $\begin{array}{c}\text { Motivasi } \\
\text { Religius }\end{array}$ & \multirow{2}{*}{116} & Mean & Min & Maks & SD & Mean & Min & Maks & SD \\
\cline { 3 - 10 } & 75 & 30 & 120 & 15 & 55 & 34 & 114 & 11,3 \\
\hline
\end{tabular}

Interpretasi dan kategorisasi motivasi religius peserta didik di Madrasah Aliyah Negeri 1 Kota Makassar dilakukan dengan model distribusi normal. Skor dikategorisasikan menjadi tiga yaitu, tinggi, sedang dan rendah dengan gambaran sebagai berikut:

Interpretasi Motivasi religius Peserta Didik

Madrasah Aliyah Negeri 1 Kota Makassar.

\begin{tabular}{|c|c|c|c|c|}
\hline Interval & Norma & Frekuensi & Kategori & Persentase \\
\hline$>\mathrm{M}+1 \mathrm{SD}$ & $>66$ & 12 & Tinggi & $10,3 \%$ \\
\hline $\mathrm{M}-1 \mathrm{SD} \leq \mathrm{M}+1 \mathrm{SD}$ & $43-66$ & 92 & Sedang & $79,4 \%$ \\
\hline$<\mathrm{M}-1 \mathrm{SD}$ & $<43$ & 12 & Rendah & $10,3 \%$ \\
\hline Jumlah & & $\mathbf{1 1 6}$ & & $\mathbf{1 0 0} \%$ \\
\hline
\end{tabular}

Dari tabel interpretasi motivasi religius peserta didik di atas dapat diketahui bahwa motivasi religius peserta didik dengan kategori tinggi sebanyak 12 orang atau 10,3 persen, sedangkan motivasi religius peserta didik dengan kategori sedang sebanyak 92 orang atau 79,4 persen dan motivasi religius peserta didik dengan kategori rendah sebanyak 12 orang atau 10,3 persen. Hal ini menunjukkan bahwa motivasi religius di Madrasah Aliyah Negeri 1 Kota Makassar tergolong sedang. 
Pelajaran Agama dan pelajaran Muatan Lokal (mulok) keagamaan adalah salah satu faktor pendukung dalam meningkatkan motivasi religius peserta didik di sekolah. Organisasi ekstrakurikuler pun seperti organisasi remaja masjid, rohis dan pramuka yang setiap organisasi tersebut memiliki kegiatan yang mendukung peningkatan motivasi religius. Peran pendidik juga dituntut untuk tidak pernah berhenti dalam pembinaan dan bimbingan keagamaan sehingga motivasi peserta didik semakin baik. Karena hal tersebut sesuai dengan visi dan misi sekolah, disamping itu, para pendidik membiasakan peserta didik untuk menutup auarat dan melaksanakan shalat berjamaah di masjid.

\section{Gambaran Prestasi Belajar Peserta Didik Madrasah Aliyah Negeri 1 Kota Makassar}

Berdasarkan hasil analisis deskriptif prestasi belajar peserta didik Madrasah Aliyah Negeri 1 Kota Makassr, maka kita dapat mengetahui beberapa informasi meliputi nilai rata-rata, median, nilai maksimum, nilai minimum dan standar deviasi peserta didik. Hasil analisis data tersebut diperlihatkan secara jelas pada tabel berikut:

Tabel Analisis Statistik Prestasi Belajar Peserta Didik Madrasah Aliyah Negeri 1 Kota Makassar

\begin{tabular}{|c|c|c|c|c|c|}
\hline Variabel & \multicolumn{5}{|c|}{ Uraian } \\
\hline Prestasi & Mean & Median & Maks & Min & SD \\
\cline { 2 - 6 } Belajar & 80,73 & 81 & 87 & 73 & 2,76 \\
\hline
\end{tabular}

Tabel di atas memperlihatkan nilai hasil analisis statistik deskriptif penelitian. Besarnya rata-rata (mean) adalah 80,73 dan nilai median adalah 81 . Nilai terendah siswa adalah 73 dan nilai tertinggi adalah 87. Adapun nilai standar deviasi sebesar 2,76. Range (rentang nilai) prestasi belajar dapat diperoleh sebesar 14 karena rentang nilainya berada pada poin 73 sampai 87

Interpretasi dan kategorisasi prestasi belajar peserta didik di Madrasah Aliyah Negeri 1 Kota Makassar dilakukan dengan model distribusi normal. Skor dikategorisasikan menjadi tiga yaitu, tinggi, sedang dan rendah dengan gambaran sebagai berikut:

Interpretasi Prestasi Belajar Peserta Didik Madrasah Aliyah Negeri 1 Kota Makassar

\begin{tabular}{|c|c|c|c|c|}
\hline Interval & Norma & Frekuensi & Kategori & Persentase \\
\hline$>\mathrm{M}+1 \mathrm{SD}$ & $>84$ & 6 & Tinggi & $5,2 \%$ \\
\hline $\mathrm{M}-1 \mathrm{SD} \leq \mathrm{M}+1 \mathrm{SD}$ & $78-84$ & 98 & Sedang & $84,5 \%$ \\
\hline$<\mathrm{M}-1 \mathrm{SD}$ & $<78$ & 12 & Rendah & $10,3 \%$ \\
\hline Jumlah & & $\mathbf{1 1 6}$ & & $\mathbf{1 0 0} \%$ \\
\hline
\end{tabular}


Berdasarkan tabel diatas diperoleh kategori prestasi belajar peserta didik Madrasah Aliyah Negeri 1 Kota Makassar yaitu : terdapat 12 orang peserta didik pada kategori rendah dengan persentase $10,3 \%$, sedangkan kategori sedang terdapat 98 orang peserta didik dengan persentase $84,5 \%$. serta 6 orang peserta didik dengan kategori tinggi dengan persentase 5,2\%. Dengan demikian dapat disimpulkan bahwa persentase prestasi belajar peserta didik Madrasah Aliyah Negeri 1 Kota Makassar berada pada kategori sedang.

\section{Hubungan Motivasi Religius dengan Prestasi Belajar peserta didik Madrasah Aliyah Negeri 1 Kota Makassar}

Untuk memperoleh hasil hubungan motivasi religius dengan prestasi belajar peserta didik di Madrasah Aliyah Negeri 1 Makassar serta untuk menguji hipotesis yang diajukan dalam penelitian digunakan pengolahan data dengan SPSS 23 for windows diperoleh output untuk koefisien korelasi berdasarkan tabel berikut:

Tabel 5.0 Correlations Tabel

\begin{tabular}{|ll|r|r|}
\hline & & Motivasi Religius & Prestasi Belajar \\
\hline \multirow{2}{*}{ Motivasi } & Pearson Correlation & $.318^{* * *}$ & $.233^{*}$ \\
Religius & Sig. (2-tailed) & .001 & .012 \\
& $\mathrm{~N}$ & 116 & 116 \\
& Pearson Correlation & $.233^{*}$ & $.318^{* *}$ \\
Prestasi Belajar & Sig. (2-tailed) & .012 & .001 \\
& $\mathrm{~N}$ & 116 & 116 \\
\hline
\end{tabular}

**. Correlation is significant at the 0.01 level (2-tailed).

*. Correlation is significant at the 0.05 level (2-tailed).

Tabel di atas menunjukkan koefisian korelasi sebesar 0,233 dengan signifikansi sebesar 0,001. Berdasarkan data tersebut di atas maka dapat dilakukan pengujian hipotesis dengan membandingkan taraf signifikansi ( $p$-value) dengan acuan jika signifikansi > 0,05 maka Ho diterima, jika signifikansi < 0,05, maka Ho ditolak dan Ha diterima. Pada kasus ini terlihat bahwa koefisien korelasi adalah 0,233 dengan signifikansi 0,001. Karena signifikansi $<0,05$ maka Ho ditolak dan Ha diterima. Artinya ada hubungan yang signifikan antara motivasi religius dengan prestasi belajar peserta didik.

\section{B. Pembahasan}

\section{Motivasi Religius Peserta Didik Madrasah Aliyah Negeri 1 Kota Makassar.}

Agama sebagai pijakan memiliki peran yang sangat besar dalam proses kehidupan manusia, agama telah mengatur pola hidup baik dalam hubungan dengan Tuhan maupun dalam hubungan dengan sesama. Agama mengajarkan yang baik dan tidak menyesatkan penganutnya, agama sebagai benteng diri remaja dalam menghadapi berbagai tantangan. 
Peserta didik di Madrasah Aliyah Negeri 1 Kota Makassar adalah remaja yang mengalami masa transisi dari anak-anak ke masa dewasa.

Adanya keinginan untuk mencari identitas diri, rasa ingin tahu yang tinggi menyebabkan remaja berusaha untuk mencoba sesuatu hal yang baru. Terjadinya konflik batin antara ajaran agama dan norma masyarakat dengan keinginan yang tertanam dalam diri remaja sehingga secara psikologis menimbulkan kecemasan dan ketegangan dalam dirinya. Periode remaja menurut Hurlock merupakan periode keraguan religiusitas. Yang dimaksud dengan keraguan religiusitas tersebut adalah Tanya-jawab religius. Para remaja ingin mempelajari agama berdasarkan pengertian intelektual dan tidak ingin menerima begitu saja, mereka meragukan agama bukan karena ingin menjadi atheis melainkan karena mereka ingin menerima agama sebagai suatu yang bermakna. ${ }^{19}$

Penanaman nilai-nilai religius sebagai usaha memelihara dan mengembangkan fitrah anak mendapat perhatian yang sangat penting baik dalam ligkungan keluarga dan sekolah. Dalam lingkungan sekolah menjadikan anak yang beriman dan bertaqwa merupakan tujuan dari pendidikan. Hasil analisis data menunjukkan bahwa tingkat motivasi religius peserta didik Madrasah Aliyah Negeri 1 Kota Makassar dengan persentase $10,3 \%$ tinggi, 79,4\% sedang dan 10,3\% rendah, dari hasil analisis tersebut menunjukkan bahwa tingkat motivasi religius peserta didik di Madrasah Aliyah Negeri 1 Kota Makassar adalah sedang, dan hasil wawancara dengan guru-guru menyatakan bahwa tingkat religiusitas peserta didik adalah baik dan akan terus berupaya membina dan membimbing peserta didik lebih baik lagi karena hal tersebut merupakan visi dan misi sekolah.

Muslim mengatakan bahwa motivasi religius juga dapat didefinisikan sebagai gerakan manusia yang berasal dari respons terhadap sistem Ilahi, sehingga orang dapat mengekspresikannya dalam bentuk tindakan dan pemikiran. ${ }^{20}$ Dapat disimpulkan, motivasi religius adalah sesuatu yang ada pada individu atau seseorang yang mendorong perilaku untuk mencapai tujuan tertentu yang berkaitan dengan keilahian, penghargaan, pemahaman dan praktik doktrin atau kepercayaan agama yang terkandung dalam agamanya.

Motivasi religius terkait langsung dengan perjalanan spiritual seseorang yang mencari kebahagiaan Allah swt. Secara garis besar, motivasi religius terbagi menjadi dua jenis, yaitu motivasi intrinsik adalah motivasi untuk mendapatkan kebenaran melalui kitab suci melalui pemahaman eksternal, motivasi eksternal adalah adanya rangsangan eksternal, karena keturunan atau lingkungan memilih Islam. ${ }^{21}$

Pada variabel motivasi religius ini rerata hipotetik lebih besar dari rerata empirik, hal ini berarti bahwa kecenderungan religiusitas peserta didik adalah tidak tinggi,

19Elizabeth B. Hurlock, Psikologi Perkembangan; Suatu Pendekatan Sepanjang RentangKehidupan. (Edisi ke V, Jakarta; Erlangga:2002). h. 222

20Muslim A. Kadir, Ilmu Islam Terapan (Cet. 3; Yogyakarta: Pustaka Pelajar, 2013) h. 44.

21Ramayulis, Psikologi Agama (Jakarta: Kalam Mulia, 2010). h. 76. 
sedangkan standar deviasi hipotetik lebih besar dari standar deviasi empirik, hal ini menunujukkan bahwa motivasi religius peserta didik memiliki variasi yang rendah atau cenderung seragam. Meningkatkan motivasi religius pada diri peserta didik tidak hanya ditanamkan sejak dini dalam lingkungan keluarga, tetapi juga pada lingkungan sekolah dan masyarakat. Nilai-nilai religius pada peserta didik yang diajarkan di sekolah, diharapkan mampu membawa dampak positif pada lingkungan keluarga dan masyarakat.

Meningkatkan motivasi religius pada diri peserta didik tidak hanya ditanamkan sejak dini dalam lingkungan keluarga, tetapi juga pada lingkungan sekolah dan masyarakat. Nilai-nilai religius pada peserta didik yang diajarkan di sekolah, diharapkan mampu membawa dampak positif pada lingkungan keluarga dan masyarakat.

Motivasi religius yang tertanam pada diri peserta didik diharapkan berfungsi sebagai pendorong, pengarah, dan sekaligus sebagai penggerak perilaku peserta didik untuk mencapai prestasi belajar yang baik. Pendidik merupakan faktor yang penting untuk mengusahakan terlaksananya fungsi-fungsi tersebut dengan cara dan terutama memenuhi kebutuhan peserta didik. Di dalam al-qur'an dijelaskan bahwa orang-orang yang senantiasa memotivasi dirinya untuk menanamkan religiusitas pada dirinya, meningkatkan ketakwaan kepada Allah akan memperoleh prestasi berupa rejeki dan kecukupan dalam hidupnya

Hasil penellitian ini menunjukkan bahwa dalam lingkungan sekolah, pendidik merupakan orang yang bertanggung jawab untuk menanamkan nilai-nilai dan meningkatkan motivasi religius pada peserta didik, hal ini agar pemahaman dan pengamalan nilai-nilai religius yang dimiliki peserta didik dapat mendorong untuk mencapai prestasi dalam belajar. Dari hasil penelitian diperoleh hasil yang menunjukkan ada hubungan yang signifikan antara motivasi religius dengan prestasi belajar peserta didik di Madrasah Aliyah Negeri 1 Makassar

\section{Prestasi Belajar Peserta Didik Madrasah Aliyah Negeri 1 Kota Makassar.}

Hasil analisis data menunjukkan bahwa untuk mengetahui gambaran prestasi belajar peserta didik Madrasah Aliyah Negeri 1 Kota Makassar dapat dilihat pada nilai yang diperoleh peserta didik dalam buku rapor. Prestasi belajar merupakan perubahan tingkah laku yang dapat mencerminkan perubahan yang terjadi sebagai prestasi belajar peserta didik, baik yang berdimensi cipta dan rasa maupun karsa. Kunci pokok untuk memperoleh ukuran dan data prestasi belajar peserta didik adalah mengetahui garis-garis besar indikator sebagai pentunjuk adanya prestasi belajar yang dikaitkan dengan jenis prestasi belajar yang hendak diungkapkan atau diukur.

Prestasi belajar peserta didik Madrasah Aliyah Negeri 1 Kota Makassar yang peneliti ambil berdasarkan prestasi akademik yang berasal dari nilai rapor pada semester ganjil tahun pelajaran 2017/2018. Nilai prestasi belajar semester tersebut adalah nilai yang dijadikan sebagai bahan penelitian. Hasil penelitian menyatakan bahwa jumlah nilai 
peserta didik Madrasah Aliyah Negeri 1 Kota Makassar mendapatkan besarnya rata-rata (mean) adalah 80,73dan nilai median adalah 81. Nilai terendah siswa adalah 73 dan nilai tertinggi adalah 87. Adapun nilai standar deviasi sebesar 2,76. Range (rentang nilai) prestasi belajar dapat diperoleh sebesar 14 karena rentang nilainya berada pada poin 73 sampai 87.

Terdapat 12 orang peserta didik pada kategori rendah dengan persentase $10,3 \%$, sedangkan kategori sedang terdapat 98 orang peserta didik dengan persentase $84,5 \%$. serta 6 orang peserta didik dengan kategori tinggi dengan persentase 5,2\%. Dengan demikian dapat disimpulkan bahwa persentase prestasi belajar peserta didik Madrasah Aliyah Negeri 1 Kota Makassar berada pada kategori sedang

Data tersebut dapat disimpulkan bahwa prestasi belajar Madrasah Aliyah Negeri 1 Kota Makassar secara umum pada kategori baik. Melihat hasil penelitian yang peneliti lakukan menjadikan pemikiran peneliti untuk dapat memberi sumbangsih pemikiran dan ide-ide kepada lembaga sekolah pada umumnya dan khususnya para pendidik, serta peserta didik itu sendiri. Sumbangsih pemikiran lewat hasil penelitian ini diharapkan ke depan menjadikan adanya peningkatan prestasi belajar peserta didik Madrasah Aliyah Negeri 1 Kota Makassar.

\section{Hubungan Sikap Disiplin dan Motivasi Religius dengan Prestasi Belajar Peserta Didik Madrasah Aliyah Negeri 1 Kota Makassar}

Hasil penelitian menyatakan bahwa ada hubungan yang signifikan antara motivasi religius dengan prestasi belajar peserta didik yang koefisiensi korelasi 0,191 dan signifikansinya berada pada 0,040 menunjukkan hubungan sedang. Signifikan artinya mempunyai makna "benar" tidak didasarkan secara kebetulan. Peneliti menggunakan angka signifikansi sebesar 0,05 .

Penggunaan angka tersebut didasarkan pada tingkat kepercayaan yang diinginkan oleh peneliti dengan pengertian bahwa tingkat kepercayaan atau bahasa umumnya keinginan kita untuk memeroleh kebenaran dalam riset adalah 95\% dengan kriteria jika angka signifikansi hasil penelitian $<0,05$ maka maka hubungan kedua variabel signifikan.

Meningkatkan motivasi religius pada diri peserta didik tidak hanya ditanamkan sejak dini dalam lingkungan keluarga, tetapi juga pada lingkungan sekolah dan masyarakat. Nilai-nilai religius pada peserta didik yang diajarkan di sekolah, diharapkan mampu membawa dampak positif pada lingkungan keluarga dan masyarakat.

Motivasi religius yang tertanam pada diri peserta didik diharapkan berfungsi sebagai pendorong, pengarah, dan sekaligus sebagai penggerak perilaku peserta didik untuk mencapai prestasi belajar yang baik. Pendidik merupakan faktor yang penting untuk mengusahakan terlaksananya fungsi-fungsi tersebut dengan cara dan terutama memenuhi kebutuhan peserta didik. Di dalam alquran dijelaskan bahwa orang-orang yang senantiasa memotivasi dirinya untuk menanamkan religiusitas pada dirinya, 
meningkatkan ketakwaan kepada Allah akan memperoleh prsetasi berupa rejeki dan kecukupan dalam hidupnya

Hasil penellitian ini menunjukkan bahwa dalam lingkungan sekolah, pendidik merupakan orang yang bertanggung jawab untuk menanamkan nilai-nilai dan meningkatkan motivasi religius pada peserta didik, hal ini agar pemahaman dan pengamalan nilai-nilai relgius yang dimiliki peserta didik dapat mendorong untuk mencapai prestasi dalam belajar. Dari hasil penelitian diperoleh hasil yang menunjukkan ada hubungan yang signifikan antara motivasi religius dengan prestasi belajar peserta didik di Madrasah Aliyah Negeri 1 Kota Makassar.

Hasil hubungan antara motivasi religius dengan prestasi belajar peserta didik menunjukkan hubungan positif yang signifikan, artinya hubungan antara kedua variabel linear atau searah. Jadi jika variabel motivasi religius tinggi maka variabel prestasi belajar tinggi, begitu pula sebaliknya. Pengaruh signifikan tersebut didukung dengan adanya nilai koefisiensi korelasi antara variabel motivasi religius dengan prestasi belajar peserta didik sebesar 0,233 dengan nilai signifikansi $0,12<0,05$ motivasi religius memiliki hubungan yang signifikan dengan prestasi belajar. Hal ini menunjukkan bahwa upaya peningkatan motivasi religius peserta didik bukan hanya sekedar menanamkan doktrin keagamaan semata tapi juga dapat meningkatkan prestasi belajar yang nantinya berdampak pada kemajuan peserta didik dan lembaga pendidikannya.

Hipotesis dalam penelitian ini adalah terdapat hubungan motivasi religius dengan prestasi belajar peserta didik di Madrasah Aliyah Negeri 1 Kota Makassar. Hasil analisis data menunjukkan adanya hubungan yang signifikan antara variabel tersebut, hal ini menunjukkan bahwa setiap sekolah menginginkan peserta didiknya menjadi anak yang bukan hanya unggul dalam prestasi tetapi juga religius. Olehnya itu pihak sekolah atau pendidik sangat besar peranannya dalam menanamkan sikap religius dalam diri peserta didik.

Hasil tersebut sejalan dengan teori yang mendukung dalam penelitian ini bahwa dengan motivasi yang timbul pada diri peserta didik akan pemahaman dan penanaman nilai religius yang dipelajarinya maka akan medorong kesadaran untuk senantiasa menuntut ilmu dan mengembangkan diri yang berujung pada peningkatan prestasi belajarnya.

\section{KESIMPULAN}

1. Motivasi religius peserta didik Madrasah Aliyah Negeri 1 Makassar dapat dilihat dari hasil respon atau jawaban subjek terhadap skala yang diberikan yaitu model sebaran frekuensi motivasi religius peserta didik memiliki persentase terbanyak sebesar 79,4\% termasuk pada kategori sedang dengan nilai rata- rata sebesar 55 . Dengan demikian, peserta didik Madrasah Aliyah Negeri 1 Makassar memiliki motivasi religius kategori sedang. 
2. Prestasi belajar peserta didik Madrasah Aliyah Negeri 1 Makassar dapat dilihat pada perolehan nilai hasil belajar peserta didik dengan persentase terbanyak sebesar 84,5\% termasuk pada kategori sedang dan nilai rata- rata sebesar 80,73. Hal ini menunjukkan bahwa prestasi belajar peserta didikMadrasah Aliyah Negeri 1 Makassar termasuk dalam kategori sedang.

3. Hubungan motivasi religius dengan prestasi belajar peserta didik ditunjukkan oleh tabel Correlations yang menggambarkan koefisiensi korelasi sebesar 0,233 dan terlihat bahwa pada nilai signifikansi berada pada angka 0,012 dengan demikian dapat disimpulkan bahwa koefisisen korelasi signifikan atau motivasi religius berhubungan secara signifikan terhadap prestasi belajar peserta didik.

4. Hubungan motivasi religius dengan prestasi belajar peserta didik ditunjukkan oleh gambaran koefisiensi korelasi sebesar 0,233 dan terlihat bahwa pada nilai signifikansi berada pada angka 0,012 dengan demikian dapat disimpulkan bahwa koefisisen korelasi signifikan atau motivasi religius berhubungan secara signifikan terhadap prestasi belajar peserta didik.

5. Motivasi religius merupakan salah satu unsur penentu keberhasilan seseorang peserta didik. Walaupun tidak dapat dipungkiri bahwa dalam proses pembelajaran, seorang pendidik sering mendapatkan tantangan yang sangat mendasar ketika dihadapkan pada kenyataan hidup siswa. Namun seorang pendidik harus dapat menghadapi berbagai sikap peserta didik yang berbedabeda.

\section{DAFTAR PUSTAKA}

Ahmadi, Psikologi Sosial. Cet. III; Jakarta: PT. Rineka Cipta, 2004.

Anni, Tri Chatarina. Psikologi Belajar. Semarang: UPT MKK UNNES, 2007.

Desmita, Psikologi Perkembangan. Bandung: PT. Remaja Rosdakarya, 2008.

Djamarah, Syaiful B. Psikologi Belajar. Cet. III; Jakarta: PT. Rineka Cipta, 2011.

Gunarsa, Singgih D. Psikologi Olahraga Prestasi. Cet. I; Jakarta: Gunung Mulia, 2008.

Hurlock, Elizabeth B. Psikologi Perkembangan; Suatu Pendekatan Sepanjang RentangKehidupan. Cet. V; Jakarta: Erlangga: 2002.

Kadir, Muslim A. Ilmu Islam Terapan.Cet. III; Yogyakarta: Pustaka Pelajar, 2013.

Langgulung, Hasan. Manusia dan Pendidikan Suatu Analisa Psikologi dan Pendidikan. Cet. III; Jakarta: al-Huda Zikra, 1995.

Ramayulis, Psikologi Agama. Cet. I; Jakarta: Kalam Mulia, 2010. 
Sudjana, NanaPenilaian Hasil Proses Belajar Mengajar.Cet. XV; Bandung: Remaja Rosdakarya, 2010.

Tohirin. Psikologi Pembelajaran Pendidikan Agama Islam (Berbasis Integrasi dan Kompetensi) Ed. I. Cet. III; Jakarta: Raja Grafindo Persada, 2008. 